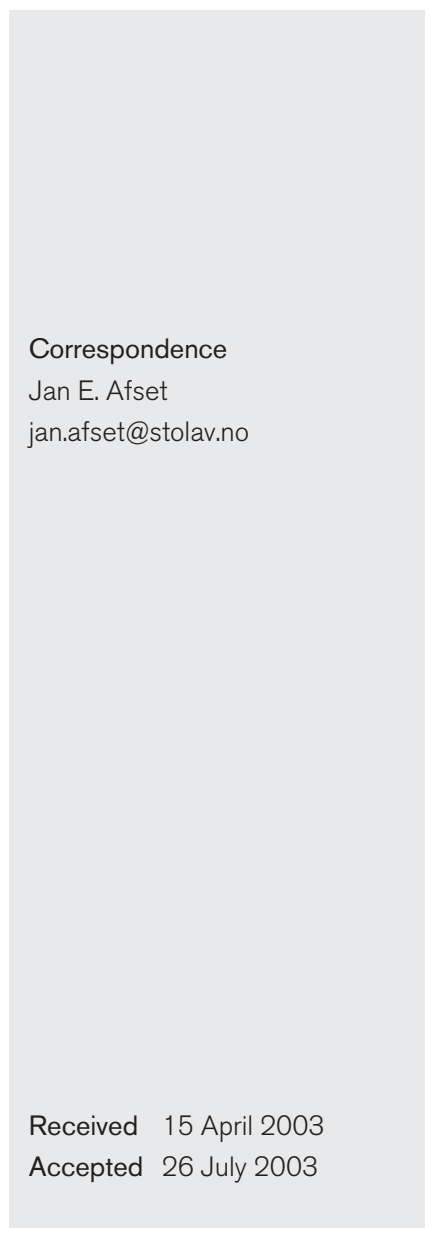

\title{
High prevalence of atypical enteropathogenic Escherichia coli (EPEC) in Norwegian children with diarrhoea
}

\author{
Jan E. Afset, ${ }^{1}$ Kåre Bergh ${ }^{1,2}$ and Lars Bevanger ${ }^{1,2}$ \\ ${ }^{1}$ Laboratory of Medical Microbiology, St Olav's Hospital, University Hospital, N-7006 Trondheim, \\ Norway \\ ${ }^{2}$ Department of Laboratory Medicine, Children's and Women's Health, Faculty of Medicine, \\ Norwegian University of Science and Technology, Trondheim, Norway
}

\begin{abstract}
The aim of the present study was to investigate the relative contribution of enteropathogenic Escherichia coli (EPEC) as a cause of infectious diarrhoea in Norwegian children. Data from faecal specimens from children $<2$ years old with diarrhoea during the year 2001 were analysed. E. coli isolates with the attaching and effacing genotype $\left(\mathrm{eae}^{+}\right)$were examined for the presence of the bundle-forming pilus $(b f p A)$ and Shiga toxin genes by PCR, and for genetic relatedness by PFGE. During the 1 -year period, 598 specimens from 440 patients $<2$ years old were analysed. Potential enteric pathogens were identified in 124 patients (28.2\%). EPEC was the most frequently identified agent (44 patients), followed by rotavirus (41 patients), Campylobacter jejuni (17 patients) and adenovirus (1 7 patients). All other agents were detected in five patients or less. Only one of the eae ${ }^{+}$ E. coli isolates was classified as typical EPEC $\left(b f p A^{+}\right)$. Among the 43 isolates that were classified as atypical EPEC $\left(b f p A^{-}\right)$, eight strains belonged to EPEC serogroups, whereas the majority of strains $(n=35)$ were not agglutinated by EPEC antisera. None of the EPEC isolates were genetically related. This study demonstrates that atypical EPEC of non-EPEC serogroups is highly prevalent among Norwegian children with diarrhoea.
\end{abstract}

\section{INTRODUCTION}

Infectious diarrhoea is one of the world's leading causes of morbidity and mortality, resulting in about two million deaths per year (World Health Organization, 2002). The majority of cases of serious diarrhoea occur among children in developing countries (World Health Organization, 1995). In contrast to third-world countries, paediatric infectious diarrhoea is rarely fatal in industrialized countries. It does, however, frequently cause visits to physicians, as well as lost work-time for parents, and therefore gives rise to considerable medical expense (Avendaño et al., 1993).

After the discovery of enteropathogenic Escherichia coli (EPEC) as a cause of childhood diarrhoea in 1945, EPEC was diagnosed frequently as a cause of paediatric diarrhoea in developed countries over the next three decades (Levine \& Edelman, 1984). Then, for unknown reasons, the incidence of EPEC declined in this part of the world (Nataro \& Kaper, 1998).

Abbreviations: A/E, attaching and effacing; EAF, EPEC adherence factor; EHEC, enterohaemorrhagic Escherichia coli; EPEC, enteropathogenic E. coli.
For many years, diagnosis of EPEC was based on $\mathrm{O}: \mathrm{H}$ serotype identification (Levine \& Edelman, 1984). During the last two decades, the pathogenic mechanism of EPEC infection has been clarified (Nataro \& Kaper, 1998); this has resulted in a change in diagnostic methods from serogrouping to phenotypic and genotypic methods.

The central mechanism of EPEC pathogenesis is a lesion called 'attaching and effacing' (A/E), which is characterized by intimate adherence of bacteria to the intestinal epithelium (Vallance \& Finlay, 2000). The eae gene, which is located in the 'locus of enterocyte effacement' (LEE) pathogenicity island, and the $b f p A$ gene, located on a plasmid called the EPEC adherence factor (EAF), have both been used for identification of EPEC and for subdivision of this group of bacteria into typical and atypical strains (Nataro \& Kaper, 1998). E. coli strains with the A/E genotype $\left(e a e^{+}\right)$that harbour the EAF plasmid $\left(b f p A^{+}\right)$are classified as 'typical EPEC'; most of these strains belong to certain $\mathrm{O}: \mathrm{H}$ serotypes. Strains with the $\mathrm{A} / \mathrm{E}$ genotype that do not posses the EAF plasmid $\left(b f p A^{-}\right)$are classified as 'atypical EPEC'. E. coli strains with the $e a e^{+}$genotype that harbour Shiga toxin genes (stxl and/or stx2) are classified as enterohaemorrhagic E. coli (EHEC). 
Recently, after the introduction of new molecular diagnostic methods, EPEC has again been reported from several developed countries (Scotland et al., 1991; Rademaker et al., 1993; Morelli et al., 1994; Forestier et al., 1996; Giammanco et al., 1996; Bokete et al., 1997; Pelayo et al., 1999; Tompkins et al., 1999; Svenungsson et al., 2000; Keskimäki et al., 2001; Knutton et al., 2001). The aim of the present study was to investigate the relative contribution of EPEC among other identifiable causes of infectious diarrhoea in Norwegian children.

\section{METHODS}

Patients. Data from analysis of clinical stool specimens received by the laboratory during the year 2001 from children $<2$ years of age were reviewed. Information on prolonged diarrhoea ( $\geqslant 2$ weeks duration at the time of examination by physician) was collected either from hospital records (hospitalized patients) or from the referral form (outpatients).

Culture and identification methods. Culture and biochemical identification of bacterial enteropathogens were done according to standard microbiological methods.

Bacterial growth on a primary-culture plate was agglutinated with polyspecific O-antisera Anti coli I (O26, O44, O114, O125, O142 and O158), Anti coli II (O55, O86, O111, O119, O126, O127 and O128) and Anti coli III (O157) according to the manufacturer's instructions (Sifin). Strains that were agglutinated by polyspecific antisera were retested by using monospecific $\mathrm{O}: \mathrm{K}$ antisera at the Norwegian Institute of Public Health (Sifin and in-house antisera).

PCR. Screening for the presence of $e a e^{+}$and $s t x^{+}$bacterial strains was based on PCR of $2-3 \mathrm{~cm}$ streaks of bacterial growth on primary-culture plates. If the streak was PCR-positive, four distinct colonies were subcultured from the same primary-culture plate (stored at $4{ }^{\circ} \mathrm{C}$ ) and retested. Isolates with the $e a e^{+}$genotype were stored at $-70{ }^{\circ} \mathrm{C}$ until they were analysed for the presence of the plasmid-encoded bundleforming pilus $(b f p A)$ gene.

Bacterial growth from streaks was suspended in $4 \mathrm{ml}$ physiological saline and further diluted $1: 100$. From agar plates with pure subculture, one bacterial colony was suspended in $1 \mathrm{ml}$ physiological saline. Lysis of bacterial cells in suspension was done by heating at $94{ }^{\circ} \mathrm{C}$ for $15 \mathrm{~min}$. Amplification of the eae gene was performed in a total volume of $50 \mu \mathrm{l}$, which contained $50 \mu \mathrm{M}$ each dNTP, $0.5 \mu \mathrm{M}$ each primer, $5 \mu \mathrm{l} 10 \times \mathrm{PCR}$ buffer (Roche), $1.5 \mathrm{mM} \mathrm{MgCl}_{2}, 1 \mathrm{U}$ AmpliTaq Gold polymerase (Roche), $0.025 \%$ BSA and $2 \mu \mathrm{l}$ bacterial lysate as template. Other amplification reactions were carried out under similar conditions, except for the following: for detection of the stx 1 and stx2 genes, multiplex amplification was carried out with $100 \mu \mathrm{M}$ (each) dNTP and no BSA, and amplification of the ial gene of enteroinvasive E. coli was performed without BSA. Primers and cycling conditions are listed in Table 1. For all amplification reactions, the mixture was heated at $94{ }^{\circ} \mathrm{C}$ for $15 \mathrm{~min}$ prior to thermocycling. The mixture was held at $72{ }^{\circ} \mathrm{C}$ for 7 min after the final cycle before cooling at $4{ }^{\circ} \mathrm{C}$. Amplified products were analysed by $2 \%$ agarose gel electrophoresis and visualized by staining with ethidium bromide. As positive controls for PCR, clinical isolates of E. coli O157: $\mathrm{H} 7$ (eae, stx1 and stx2), E. colistrain B171 (bfpA) and E. coli $\mathrm{O} 124$ : $\mathrm{H} 30$ (ial) were used.

Genotyping of EPEC strains. E. coli isolates with the eae $e^{+}$genotype were analysed for genetic relatedness by PFGE according to standard methods. XbaI as the restriction enzyme and the following electrophoretic conditions were used: $14^{\circ} \mathrm{C}$, linear ramp of $5-60 \mathrm{~s}$ over $24 \mathrm{~h}$, $120^{\circ}$ switch angle and a gradient of $6 \cdot 0 \mathrm{~V} \mathrm{~cm}^{-1}$. Analysis of fragments was done by using Fingerprinting II software (Bio-Rad) and by visual inspection with the criteria of Tenover et al. (1995). Similarities between strains were analysed by the UPGMA clustering method, using the Dice coefficient at $2.5 \%$ tolerance.

Other methods. Stool specimens were examined for adenovirus by enzyme immunoassay (IDEIA; Dako), viral cell culture and PCR, and for rotavirus antigens by enzyme immunoassay (IDEIA; Dako). In addition to the routine analysis above, some specimens were tested for

Table 1. PCR for detection of enteropathogenic, enterohaemorrhagic and enteroinvasive E. coli

Abbreviations: $b f p A$, bundle-forming pilus gene; eae, attaching and effacing-associated gene; EIEC, enteroinvasive E. coli; ial, invasion-associated locus of EIEC; stx, Shiga toxin gene. Forward and reverse primers are indicated by F and R, respectively.

\begin{tabular}{|c|c|c|c|c|c|c|}
\hline Category & Target & Nucleotide sequence $\left(5^{\prime} \rightarrow 3^{\prime}\right)$ & $\begin{array}{l}\text { Amplification } \\
\text { conditions }\end{array}$ & No. cycles & $\begin{array}{l}\text { Size of amplified } \\
\text { product (bp) }\end{array}$ & References \\
\hline EPEC (all) & eae & $\begin{array}{l}\text { F, GTGGCGAATACTGGCGAGACT; } \\
\text { R, CCCCATTCTTTTTCACCGTCG }\end{array}$ & $\begin{array}{l}94^{\circ} \mathrm{C}(1 \mathrm{~min}) \\
60{ }^{\circ} \mathrm{C}(1 \mathrm{~min}) \\
72{ }^{\circ} \mathrm{C}(2 \mathrm{~min})\end{array}$ & 35 & 891 & Gannon et al. (1993) \\
\hline \multirow[t]{2}{*}{ EHEC } & $s t x 1$ & $\begin{array}{l}\text { F, AAATCGCCATTCGTTGACTACTTCT; } \\
\text { R, CAGTCGTCACTCACTGGTTTCATCA }\end{array}$ & $\begin{array}{l}94^{\circ} \mathrm{C}(1 \mathrm{~min}) \\
64^{\circ} \mathrm{C}(1 \mathrm{~min}) \\
72{ }^{\circ} \mathrm{C}(15 \mathrm{~s})\end{array}$ & 35 & 370 & Brian et al. (1992) \\
\hline & $s t \times 2$ & $\begin{array}{l}\text { F, TGCCATTCTGGCAACTCGCGATGCA; } \\
\text { R, GGATCTTCTCCCCACTCTGACACC }\end{array}$ & $\begin{array}{l}94^{\circ} \mathrm{C}(1 \mathrm{~min}) \\
64{ }^{\circ} \mathrm{C}(1 \mathrm{~min}) \\
72{ }^{\circ} \mathrm{C}(15 \mathrm{~s})\end{array}$ & 35 & 283 & Brian et al. (1992) \\
\hline $\begin{array}{l}\text { EPEC } \\
\text { (typical) }\end{array}$ & $b f p A$ & $\begin{array}{l}\text { F, AATGGTGCTTGCGCTTGCTGC; } \\
\text { R, GCCGCTTTATCCAACCTGGTA }\end{array}$ & $\begin{array}{l}94^{\circ} \mathrm{C}(1 \mathrm{~min}) \\
60{ }^{\circ} \mathrm{C}(1 \mathrm{~min}) \\
72{ }^{\circ} \mathrm{C}(2 \mathrm{~min})\end{array}$ & 30 & 326 & Gunzburg et al. (1995) \\
\hline EIEC & ial & $\begin{array}{l}\text { F, CTGGATGGTATGGTGAGG; } \\
\text { R, GGAGGCCAACAATTATTTCC }\end{array}$ & $\begin{array}{l}94^{\circ} \mathrm{C}(1 \mathrm{~min}) \\
43^{\circ} \mathrm{C}(2 \mathrm{~min}) \\
72{ }^{\circ} \mathrm{C}(3 \mathrm{~min})\end{array}$ & 26 & 320 & Schoolnik (1993) \\
\hline
\end{tabular}


other enteropathogenic agents when suspected clinically: by electron microscopy (calicivirus and astrovirus, $n=2$ ), by enzyme immunoassay for Giardia lamblia (CELISA, Cellabs; $n=105$ ), by microscopy for other parasites $(n=65)$ or by PCR for enteroinvasive E. coli $(n=1)$.

\section{RESULTS AND DISCUSSION}

\section{Patients}

During the 12-month study period, 598 stool specimens from 440 children $<2$ years old were examined. Among the study population, 135 children $(30 \cdot 7 \%)$ were $<6$ months old, $99(22.5 \%)$ were $6-11$ months old and $206(46 \cdot 8 \%)$ were 12-23 months of age, with a sex distribution of 241 male $(54 \cdot 8 \%)$ and 199 female $(45 \cdot 2 \%)$ patients.

\section{All potential enteropathogens}

A potential or established microbial pathogen was detected in 124 patients $(28.2 \%)$, either as a single agent (114 patients) or in combination with other agents (10 patients). EPEC was the most frequently identified agent (44 patients), followed by rotavirus (41 patients), Campylobacter jejuni (17 patients) and adenovirus (17 patients) (Table 2). All other agents were each diagnosed in five or fewer patients.

Table 2. Potential and established enteropathogens isolated from Norwegian children $<2$ years old with diarrhoea $(n=440)$

\begin{tabular}{|c|c|}
\hline Isolates & No. patients (\%) \\
\hline $\operatorname{EPEC}\left(e a e^{+}, s t x^{-}\right)$ & $44(10 \cdot 0)$ \\
\hline Alone & $39(8 \cdot 9)$ \\
\hline \multicolumn{2}{|l|}{ Combined with other pathogens: } \\
\hline +Campylobacter jejuni & $2(0 \cdot 5)$ \\
\hline +Rotavirus & $1(0 \cdot 2)$ \\
\hline+ Rotavirus + calicivirus $^{*}$ & $1(0 \cdot 2)$ \\
\hline +Adenovirus & $1(0 \cdot 2)$ \\
\hline $\operatorname{EHEC}\left(s t x^{+}\right) \dagger$ & $4(0 \cdot 9)$ \\
\hline Alone & $1(0 \cdot 2)$ \\
\hline Combined with Campylobacter jejuni & $3(0 \cdot 7)$ \\
\hline Non-E. coli pathogens & $76(17 \cdot 3)$ \\
\hline \multicolumn{2}{|l|}{ Alone: } \\
\hline Rotavirus & $39(8 \cdot 9)$ \\
\hline Adenovirus & $16(3 \cdot 6)$ \\
\hline Campylobacter jejuni & $11(2 \cdot 5)$ \\
\hline Salmonella spp. & $3(0 \cdot 7)$ \\
\hline Shigella spp. & $1(0 \cdot 2)$ \\
\hline Giardia lamblia* & $2(0 \cdot 5)$ \\
\hline Yersinia enterocolitica & $1(0 \cdot 2)$ \\
\hline Calicivirus $^{*}$ & $1(0 \cdot 2)$ \\
\hline \multicolumn{2}{|l|}{ Combinations of pathogens: } \\
\hline Salmonella sp. + Campylobacter jejuni & $1(0 \cdot 2)$ \\
\hline Salmonella sp. + Shigella sp. & $1(0 \cdot 2)$ \\
\hline Total & $124(28 \cdot 2)$ \\
\hline
\end{tabular}

${ }^{\star}$ Investigation done only when suspected from clinical history.

$\dagger$ Three EHEC isolates were $e a e^{+}$.

\section{EPEC}

PCR from growth on the primary-culture plate was positive for the eae gene in 65 patients $(14.8 \%)$. In 18 of these patients, however, an $e a e^{+}$organism could not be recovered after subculture of four colonies. We chose not to record these 18 patients as EPEC-positive. As these patients probably had a low number of $e a e^{+}$organisms, they were less likely to have symptomatic disease due to this organism (Nataro \& Kaper, 1998). In three patients, E. coli isolates were classified as EHEC due to the presence of the stx genes. Among the remaining 44 patients from whom EPEC was isolated, 39 had EPEC as their only diagnosed potential pathogen and five had this organism in combination with other enteropathogenic agents (Table 2). Only one patient $(0 \cdot 2 \%)$ had typical EPEC (a $b f p A^{+}$isolate), whereas 43 patients had atypical EPEC ( $b f p A^{-}$isolates).

Surprisingly, EPEC was the most frequently identified potential pathogen in this study, identified in 44 of 440 patients $(10 \cdot 0 \%)$. This is a high prevalence compared to most other reports (Forestier et al., 1996; Bokete et al., 1997; Tompkins et al., 1999; Svenungsson et al., 2000; Keskimäki et al., 2001; Knutton et al., 2001; Vieira et al., 2001). Typical EPEC $\left(b f p A^{+}\right)$was uncommon, a finding that is consistent with other reports of low prevalence of typical EPEC in Europe (Rademaker et al., 1993; Morelli et al., 1994; Forestier et al., 1996; Giammanco et al., 1996; Scotland et al., 1996; Svenungsson et al., 2000; Keskimäki et al., 2001; Knutton et al., 2001; Paciorek, 2002) and North America (Bokete et al., 1997; Caeiro et al., 1999). Atypical EPEC, which constituted all but one isolate in this study, seemed to be widely spread among children with diarrhoea in Norway.

\section{Patients admitted to hospital}

Altogether 135 patients in this study (30.7\%) were admitted to hospital. Potential enteropathogens were detected with similar frequency in admitted patients and outpatients $(n=38,28.1 \%)$. As expected, rotavirus was the most frequently identified agent in this group of patients, whereas atypical EPEC was identified in four children $(3 \cdot 0 \%)$. None of the patients with EPEC who were admitted to hospital had severe acute gastroenteritis, in contrast to 16 of the 18 patients with rotavirus infection $(88.9 \%)$. These data support the hypothesis that atypical EPEC rarely causes acute serious gastroenteritis among children in Norway.

\section{Disease duration}

Prolonged duration ( $\geqslant 2$ weeks) of gastroenteritis symptoms at the time of examination was recorded in 12 of 38 patients $(31.6 \%)$ with atypical EPEC. The fact that almost one-third of patients with atypical EPEC had a protracted course of diarrhoea was surprising and raises the question of whether atypical EPEC can cause prolonged diarrhoea. This finding could, however, also be due to the selection of patients from whom specimens were sent to the laboratory. This should be clarified in a prospective study. 


\section{Genetic relatedness among EPEC isolates}

Macrorestriction patterns of 38 EPEC strains were analysed by PFGE. Typically, XbaI digestion yielded between eight and twelve restriction fragments, whilst two strains were nontypable. Among the 36 typable strains, each displayed a unique genotypic pattern (data not shown). The genetic diversity of strains in this study demonstrates that the high prevalence ofEPEC in the paediatric population in Norway is not caused by clonal spread, but rather that there are several distinct $e a e^{+}$E. coli strains present in this patient population.

\section{Other features}

A diagnosis of EPEC was significantly more common among children who were $12-23$ months old (33/206 patients, $16.0 \%)$ than in those who were $<12$ months of age $(11 /$ $234,4.7 \%$; $\chi^{2}$ test, $\left.P<0.001\right)$. Only four of 135 patients $(3.0 \%)$ who were $<6$ months old were diagnosed with EPEC.

A marked seasonal distribution was seen in the isolation rate of EPEC strains. Twenty-one (47.7\%) EPEC isolates were identified during the 3-month period from July to September, in contrast to rotavirus, which was diagnosed mainly during the late-winter season (data not shown).

Among the four patients who were infected with EHEC, none developed haemolytic uraemic syndrome. All EHEC isolates belonged to serogroups other than O157.

\section{Atypical EPEC of non-EPEC serogroups}

Strains with the $e a e^{+}$genotype that lack the EAF plasmid $\left(b f p A^{-}\right)$and Shiga toxin genes $\left(s t x^{-}\right)$are classified as atypical EPEC by some authors only if they belong to recognized EPEC serogroups (Trabulsi et al., 2002). Strains with the $e^{e} e^{+}$genotype that do not belong to EPEC serogroups were reported recently to constitute a heterogeneous group that may resemble EHEC, enteroaggregative E. coli or diffusely adherent E. coli (Vieira et al., 2001; Trabulsi et al., 2002). However, most such strains have virulence profiles similar to those of atypical strains that belong to EPEC serogroups (Vieira et al., 2001); at least some of these strains are able to induce $\mathrm{A} / \mathrm{E}$ lesions on human intestinal biopsies (Knutton et al., 2001; Vieira et al., 2001). We therefore included all $e a e^{+}, s t x^{-}$and $b f p A^{-}$E. coli strains in the category of atypical EPEC. Among the 43 atypical EPEC strains in our study, eight $(1 \cdot 8 \%)$ belonged to recognized EPEC serogroups, whereas the majority of strains $(n=35,8.0 \%)$ were not agglutinated by EPEC antisera. Classification of EPEC strains diagnosed during the 1-year period is presented in Table 3. Atypical EPEC of non-EPEC serogroups was diagnosed more frequently in this study than the value of $1-6 \%$ that has been reported from other parts of Europe (Knutton et al., 1991, 2001; Forestier et al., 1996; Keskimäki et al., 2001) and North America (Bokete et al., 1997).

The role of atypical EPEC in endemic diarrhoea has not been established conclusively. Absence of the EAF plasmid $\left(b f p A^{-}\right)$probably results in reduced virulence (Levine
Table 3. Classification of $\mathrm{eae}^{+}$and $s t x^{-}$E. coli isolates identified among 440 Norwegian children $<2$ years old with diarrhoea

\begin{tabular}{|lcc|}
\hline Serogroup & \multicolumn{2}{c|}{ E. $\boldsymbol{c o l i}\left(\boldsymbol{e a c}^{+}, \boldsymbol{s t x}^{-}\right)$} \\
\cline { 2 - 3 } & $\boldsymbol{b} \boldsymbol{f} \boldsymbol{p} \boldsymbol{A}^{+}$ & $\boldsymbol{b} \boldsymbol{f p} \boldsymbol{A}^{-}$ \\
\hline EPEC serogroup & $1 \dagger$ & $8 \ddagger$ \\
Non-EPEC serogroup & 0 & 35 \\
Total & 1 & 43 \\
\hline
\end{tabular}

*As defined by the World Health Organization (1987).

$\dagger$ Serogroup O111: K58.

\$Serogroups O26:K60 (four isolates), O55:K59 (one isolate), O127: K63 (two isolates) and O128: K67 (one isolate).

et al., 1985), but some atypical strains have been shown to have other virulence factors that may compensate for this (Scaletsky et al., 2002; Trabulsi et al., 2002). There have been reports of atypical EPEC associated with both endemic diarrhoea (Pedroso et al., 1993; Bokete et al., 1997; Vieira et al., 2001) and outbreaks (Viljanen et al., 1990; Hedberg et al., 1997; Yatsuyanagi et al., 2002). To elucidate the role of atypical EPEC in diarrhoeal disease among Norwegian children, both epidemiological studies and further investigation of the virulence properties of these strains are warranted.

In conclusion, atypical EPEC is prevalent among small children with diarrhoea in Norway and was diagnosed in 9.8\% of patients in this study. Typical EPEC was rare and most atypical EPEC strains did not belong to recognized EPEC serogroups. Few EPEC isolates were diagnosed in hospitalized patients, supporting the hypothesis that this group of organisms does not often cause serious acute disease.

\section{ACKNOWLEDGEMENTS}

Skilful technical assistance by Grete Iversen in performing PFGE is gratefully acknowledged. We thank Dr Jørgen Lassen, Norwegian Institute of Public Health, for $\mathrm{O}: \mathrm{K}$ serogroup identification of E. coli strains.

\section{REFERENCES}

Avendaño, P., Matson, D. O., Long, J., Whitney, S., Matson, C. C. \& Pickering, L. K. (1993). Costs associated with office visits for diarrhea in infants and toddlers. Pediatr Infect Dis J 12, 897-902.

Bokete, T. N., Whittam, T. S., Wilson, R. A., Clausen, C. R., O'Callahan, C. M., Moseley, S. L., Fritsche, T. R. \& Tarr, P. I. (1997). Genetic and phenotypic analysis of Escherichia coli with enteropathogenic characteristics isolated from Seattle children. J Infect Dis 175, 1382-1389.

Brian, M. J., Frosolono, M., Murray, B. E., Miranda, A., Lopez, E. L., Gomez, H. F. \& Cleary, T. G. (1992). Polymerase chain reaction for diagnosis of enterohemorrhagic Escherichia coli infection and hemolytic-uremic syndrome. J Clin Microbiol 30, 1801-1806.

Caeiro, J. P., Mathewson, J. J., Smith, M. A., Jiang, Z. D., Kaplan, M. A. \& 
Dupont, H. L. (1999). Etiology of outpatient pediatric nondysenteric diarrhea: a multicenter study in the United States. Pediatr Infect Dis J 18, 94-97.

Forestier, C., Meyer, M., Favre-Bonte, S., Rich, C., Malpuech, G., Le Bouguenec, C., Sirot, J., Joly, B. \& De Champs, C. (1996). Enteroadherent Escherichia coli and diarrhea in children: a prospective casecontrol study. J Clin Microbiol 34, 2897-2903.

Gannon, V. P., Rashed, M., King, R. K. \& Thomas, E. J. (1993). Detection and characterization of the eae gene of Shiga-like toxin-producing Escherichia coli using polymerase chain reaction. J Clin Microbiol 31, 1268-1274.

Giammanco, A., Maggio, M., Giammanco, G., Morelli, R., Minelli, F., Scheutz, F. \& Caprioli, A. (1996). Characteristics of Escherichia coli strains belonging to enteropathogenic E. coli serogroups isolated in Italy from children with diarrhea. J Clin Microbiol 34, 689-694.

Gunzburg, S. T., Tornieporth, N. G. \& Riley, L. W. (1995). Identification of enteropathogenic Escherichia coli by PCR-based detection of the bundle-forming pilus gene. J Clin Microbiol 33, 1375-1377.

Hedberg, C. W., Savarino, S. J., Besser, J. M. \& 7 other authors (1997). An outbreak of foodborne illness caused by Escherichia coli O39: NM, an agent not fitting into the existing scheme for classifying diarrheogenic E. coli. J Infect Dis 176, 1625-1628.

Keskimäki, M., Eklund, M., Pesonen, H., Heiskanen, T. \& Siitonen, A. (2001). EPEC, EAEC and STEC in stool specimens: prevalence and molecular epidemiology of isolates. The Study Group. Diagn Microbiol Infect Dis 40, 151-156.

Knutton, S., Phillips, A. D., Smith, H. R., Gross, R. J., Shaw, R., Watson, P. \& Price, E. (1991). Screening for enteropathogenic Escherichia coli in infants with diarrhea by the fluorescent-actin staining test. Infect Immun 59, 365-371.

Knutton, S., Shaw, R., Phillips, A. D., Smith, H. R., Willshaw, G. A., Watson, P. \& Price, E. (2001). Phenotypic and genetic analysis of diarrhea-associated Escherichia coli isolated from children in the United Kingdom. J Pediatr Gastroenterol Nutr 33, 32-40.

Levine, M. M. \& Edelman, R. (1984). Enteropathogenic Escherichia coli of classic serotypes associated with infant diarrhea: epidemiology and pathogenesis. Epidemiol Rev 6, 31-51.

Levine, M. M., Nataro, J. P., Karch, H., Baldini, M. M., Kaper, J. B., Black, R. E., Clements, M. L. \& O'Brien, A. D. (1985). The diarrheal response of humans to some classic serotypes of enteropathogenic Escherichia coli is dependent on a plasmid encoding an enteroadhesive factor. J Infect Dis 152, 550-559.

Morelli, R., Baldassarri, L., Falbo, V., Donelli, G. \& Caprioli, A. (1994). Detection of enteroadherent Escherichia coli associated with diarrhoea in Italy. J Med Microbiol 41, 399-404.

Nataro, J. P. \& Kaper, J. B. (1998). Diarrheagenic Escherichia coli. Clin Microbiol Rev 11, 142-201.

Paciorek, J. (2002). Virulence properties of Escherichia coli faecal strains isolated in Poland from healthy children and strains belonging to serogroups O18, O26, O44, O86, O126 and O127 isolated from children with diarrhoea. J Med Microbiol 51, 548-556.

Pedroso, M. Z., Freymuller, E., Trabulsi, L. R. \& Gomes, T. A. (1993). Attaching-effacing lesions and intracellular penetration in HeLa cells and human duodenal mucosa by two Escherichia coli strains not belonging to the classical enteropathogenic $E$. coli serogroups. Infect Immun 61, 1152-1156.

Pelayo, J. S., Scaletsky, I. C. A., Pedroso, M. Z., Sperandio, V., Girón, J. A., Frankel, G. \& Trabulsi, L. R. (1999). Virulence properties of atypical EPEC strains. J Med Microbiol 48, 41-49.

Rademaker, C. M. A., Fluit, A. C., Jansze, M., Jansen, W. H., Glerum, J. H.
\& Verhoef, J. (1993). Frequency of enterovirulent Escherichia coli in diarrhoeal disease in The Netherlands. Eur J Clin Microbiol Infect Dis 12, 93-97.

Scaletsky, I. C. A., Michalski, J. \& Kaper, J. (2002). Identification of novel adherence genes found in atypical enteropathogenic Escherichia coli (EPEC) strains. In Abstract Book of the 3rd International EPEC Symposium, abstract no. S2.5. October 2002, Puerto Vallarta, Mexico.

Schoolnik, G. K. (1993). PCR detection of Shigella species and enteroinvasive Escherichia coli. In Diagnostic Molecular Microbiology: Principles and Applications, pp. 277-281. Edited by D. H. Persing, T. F. Smith, F. C. Tenover \& T. J. White. Washington, DC: American Society for Microbiology.

Scotland, S. M., Smith, H. R., Said, B., Willshaw, G. A., Cheasty, T. \& Rowe, B. (1991). Identification of enteropathogenic Escherichia coli isolated in Britain as enteroaggregative or as members of a subclass of attaching-and-effacing E. coli not hybridising with the EPEC adherencefactor probe. J Med Microbiol 35, 278-283.

Scotland, S. M., Smith, H. R., Cheasty, T., Said, B., Willshaw, G. A., Stokes, N. \& Rowe, B. (1996). Use of gene probes and adhesion tests to characterise Escherichia coli belonging to enteropathogenic serogroups isolated in the United Kingdom. J Med Microbiol 44, 438-443.

Svenungsson, B., Lagergren, Å., Ekwall, E., Evengård, B., Hedlund, K. O., Kärnell, A., Löfdahl, S., Svensson, L. \& Weintraub, A. (2000). Enteropathogens in adult patients with diarrhea and healthy control subjects: a 1-year prospective study in a Swedish clinic for infectious diseases. Clin Infect Dis 30, 770-778.

Tenover, F. C., Arbeit, R. D., Goering, R. V., Mickelsen, P. A., Murray, B. E., Persing, D. H. \& Swaminathan, B. (1995). Interpreting chromosomal DNA restriction patterns produced by pulsed-field gel electrophoresis: criteria for bacterial strain typing. J Clin Microbiol 33, 2233-2239.

Tompkins, D. S., Hudson, M. J., Smith, H. R. \& 8 other authors (1999). A study of infectious intestinal disease in England: microbiological findings in cases and controls. Commun Dis Public Health 2, 108-113.

Trabulsi, L. R., Keller, R. \& Tardelli Gomes, T. A. (2002). Typical and atypical enteropathogenic Escherichia coli. Emerg Infect Dis 8, 508-513.

Vallance, B. A. \& Finlay, B. B. (2000). Exploitation of host cells by enteropathogenic Escherichia coli. Proc Natl Acad Sci U S A 97, 8799-8806.

Vieira, M. A. M., Andrade, J. R. C., Trabulsi, L. R., Rosa, A. C. P., Dias, A. M. G., Ramos, S. R. T. S., Frankel, G. \& Gomes, T. A. T. (2001). Phenotypic and genotypic characteristics of Escherichia coli strains of non-enteropathogenic E. coli (EPEC) serogroups that carry eae and lack the EPEC adherence factor and Shiga toxin DNA probe sequences. J Infect Dis 183, 762-772.

Viljanen, M. K., Peltola, T., Junnila, S. Y., Olkkonen, L., Järvinen, H., Kuistila, M. \& Huovinen, P. (1990). Outbreak of diarrhoea due to Escherichia coli $\mathrm{O} 111$ : B4 in schoolchildren and adults: association of $\mathrm{Vi}$ antigen-like reactivity. Lancet 336, 831-834.

World Health Organization (1987). Programme for control of diarrheal diseases (CDD/83.3 Rev1). In Manual for Laboratory Investigations of Acute Enteric Infections, p. 27. Geneva: WHO.

World Health Organization (1995). Bridging the Gaps. The World Health Report (http://www.who.int/whr2001/2001/archives/1995/ index.htm).

World Health Organization (2002). Reducing Risks, Promoting Healthy Life. The World Health Report (http://www.who.int/whr/en/).

Yatsuyanagi, J., Saito, S., Sato, H., Miyajima, Y., Amano, K. \& Enomoto, K. (2002). Characterization of enteropathogenic and enteroaggregative Escherichia coli isolated from diarrheal outbreaks. J Clin Microbiol 40, 294-297. 